\title{
Efektivitas Pembelajaran Daring dalam Pandangan Mahasiswa Fakultas Tarbiyah dan Ilmu Keguruan Institut Agama Islam Negeri Samarinda
}

\author{
Fathiyatul Haq Mai Al Mawangir \\ IAIN Samarinda, Samarinda, Indonesia \\ fathiyatulhaq@gmail.com \\ Fulan Puspita \\ IAIN Samarinda, Samarinda, Indonesia \\ fulan.puspita@email.com
}

\begin{abstract}
The purpose of this study was to determine the views of students in the effectiveness of online learning. This study used a quantitative approach with 341 respondents of FTIK IAIN Samarinda students in academic year 2020-2021. The research data were analyzed using descriptive quantitative analysis of percentage techniques. The results showed that the average percentage value of the survey results was $62.7 \%$ which was in the good category, which means that students gave a positive view of implementing this online lecture and were willing to continue even though the Covid-19 pandemic had ended.
\end{abstract}

Keywords: Effectiveness; Online Learning; Student Views

\begin{abstract}
Abstrak
Tujuan penelitian ini adalah untuk mengetahui bagaimana pandangan mahasiswa dalam meningkatkan efektifitas pembelajaran daring. Penelitian ini menggunakan pendekatan kuantitatif dengan jumlah responden 341 mahasiswa FTIK IAIN Samarinda semester genap tahun akademik 2020-2021. Data penelitian dianalisis menggunakan analisis kuantitatif deskriptif teknik persentase. Hasil penelitian menunjukkan bahwa nilai rata-rata persentase hasil survei yaitu $62,7 \%$ yang termasuk dalam kategori baik yang artinya mahasiswa memberikan pandangan positif atas pelaksanaan perkuliahan daring ini dan bersedia dilanjutkan meskipun pandemi Covid-19 telah berakhir.
\end{abstract}

Kata kunci: Efektivitas; Pembelajaran Daring; Pandangan Mahasiswa 


\section{A. Pendahuluan}

Virtual learning yang telah diusung dari 1980 di Indonesia akhirnya menemukan momentumnya saat ini (Putra, 2020: 1; Zaking, 2020: 1). Pandemi virus Covid-19 telah mengharuskan semua pihak untuk melaksanakan kegiatan belajar mengajar berbasis internet dimulai dari jenjang sekolah hingga ke jenjang perguruan tinggi pembelajaran dilaksanakan secara daring. Pemerintah Indonesia melalui KEMENDIKBUD dan KEMENAG, menngeluarkan aturan belajar dan bekerja dari rumah (Work from Home) mulai bulan Maret tahun 2020. Disusul selanjutnya dengan dikeluarkannya surat keputusan 4 menteri nomor 01/KB/2020 yang menetapkan bahwa pelaksanaan pembelajaran/perkuliahan terutama pada perguruan tinggi wajib diselenggarakan secara online, kegiatan praktikum dan penelitian di laboratorium jika bisa dilaksanakan secara online atau waktu pelaksanannya ditunda menjadi bagian akhir semester atau dilaksanakan di semester berikutnya dengan tetap mengikuti protokol kesehatan (Direktorat Pendidikan Tinggi Kemendikbut RI, 2020: 1). Hal ini secara tidak langsung menyebabkan perguruan tinggi dipaksa untuk melakukan transformasi digital secara masif untuk proses pembelajaran.

Institut Agama Islam Negeri (IAIN) Samarinda merespon kebijakan Work from Home (WFH) dan surat keputusan 4 menteri tersebut dengan mengeluarkan kebijakan berupa perkuliahan dilakukan secara daring yang dilaksanakan sejak Maret 2020 pada tahun akademik 2019-2020 hingga saat ini tahun akademik 2020-2021. Sebelum wabah Covid-19 muncul, sebenarnya IAIN Samarinda sudah menerapkan pembelajaran daring walaupun belum secara optimal dan belum ada prosedur serta regulasi mengenai pelaksanaan pembelajaran daring.

Pembelajaran daring (dalam jaringan) atau e-learning sering dikaitkan dengan kegiatan belajar di rumah. Sehingga penggunaan teknologi informasi dan komunikasi pada proses belajar mengajar bisa dianggap sebagai e-learning (Muthuchamy \& Thiyagu, 2011; Rosenberg \& Foshay, 2002: 80; Setiawan et al., 2020: 79; Setyowati et al., 2020: 77). Pelaksanaan pembelajaran daring ini sudah banyak dilakukan di berbagai lembaga pendidikan karena model pembelajaran ini memiliki beberapa kelebihan di antaranya: 1) mampu mengatasi kejenuhan dalam belajar dengan metode biasa sehingga memberikan pengalaman yang berbeda dalam belajar, 2) mengatasi persoalan tempat dan waktu, sehingga dengan melaksanakan pembelajaran secara daring siapapun bisa melaksanakan pembelajaran dimanapun dan kapanpun dengan menggunakan alat komunikasi/laptop/komputer yang tersambung dengan jaringan internet tanpa harus pergi ke kelas, 3) dapat memotivasi untuk belajar secara mandiri (Sahroni \& Nuryuniarti, 2020: 39; Yuniarti, 2010: 66). 
Penerapan belajar dari rumah atau dalam jaringan (daring) juga mempunyai beberapa keluhan, kekurangan dan hambatan yang dirasakan oleh berbagai pihak baik dari dosen maupun mahasiswa, seperti signal yang tidak stabil, materi yang tidak sepenuhnya tersampaikan sehingga mahasiswa kurang memahami materi, serta kurangnya sarana atau media pendukung dalam pembelajaran daring. Untuk itu, penting bagi perguruan tinggi melihat pandangan mahasiswa dalam pembelajaran daring agar pelaksanaan pembelajaran daring bisa efektif.

Pentingnya pandangan mahasiswa atau respon yang diberikan oleh mahasiswa terhadap pengambilan kebijakan pembelajaran online nantinya akan memberikan pengaruh yang positif terhadap pembentukan profil lulusan perguruan tinggi tidak terkecuali pada lulusan IAIN Samarinda. Mahasiswa Fakultas Tarbiyah dan Ilmu Keguruan (FTIK) IAIN Samarinda telah dipersiapkan untuk menjadi guru yang berwawasan luas, religius, mempunyai intelektualitas dan profesionalitas di bidangnya seperti yang tertuang dalam visi misi Fakultas Tarbiyah dan Ilmu Keguruan (FTIK) IAIN Samarinda.

Visi Fakultas Tarbiyah dan Ilmu Keguruan (FTIK) IAIN Samarinda yaitu terdepan dalam mengembangkan pendidikan Islam berasaskan pada spiritualitas, intelektualitas dan profesionalitas. misi dalam mencapai visi tersebut yaitu 1) melakukan peningkatan kompetensi dari kompetensi kepemimpinan, pedagogic, professional hingga kompetensi kepribadian, 2) membangun lingkungan yang mendukung dalam pembangunan aqidah, internaslisasi nilai, dan berketerampilan berpikir kreatif, kritis serta inovatif, 3) peningkatan kelembagaan dari segi kapasitas dan mutu, 4) membudayakan tradisi penelitian dan karya ilmiah, 5) melaksanakan pelayanan yang tepat, humanis dan cepat, 6) membangun kerjasama dalam peningkatan pendidikan guru yang profesional. Adapun profesionalitas seorang guru tidak hanya dilihat dari tugas utamanya dalam transfer of knowledge akan tetapi harus mampu untuk melakukan transfer of value (Hermawan, 2020: 303).

Penelitian ini membahas mengenai pelaksanaan pembelajaran daring dengan menekankan pada pandangan mahasiswa FTIK sebagai calon guru terhadap efektifitas pembelajaran daring yang dilihat menggunakan 7 aspek yaitu aktivitas sehari-hari, pendapatan orang tua, pemakaian kuota perbulan, sinyal internet, media pembelajaran, tugas perkuliahan, dan sistem perkuliahan. Hal ini jelas berbeda dengan penelitianpenelitian yang dilakukan oleh peneliti lainnya dimana fokus penelitian sebelumnya adalah membahas bagaimana daya serap materi saat pembelajaran daring, bagaimana peningkatan nilai Ujian Akhir Semester (UAS) saat kegiatan belajar mengajar atau perkuliahan dilaksanakan secara daring dan bagaimana penggunaan aplikasi ketika dijadikan media untuk pembelajaran daring. 
Adapun beberapa penelitian tersebut yaitu; pertama, Aan Widiyono dengan judul "Efektifitas Perkuliahan Daring (Online) pada Mahasiswa PGSD di Saat Pandemi Covid 19", adapun hasil penelitiannya menyatakan bahwa pembelajaran yang dilaksanakan secara daring membuat mahasiswa kurang optimal dalam memahami bahan ajar atau materi perkuliahan yang disampaikan oleh para dosen dan rata-rata para dosen terlalu banyak memberikan tugas kepada mahasiswa dan minim penjelasan materi perkuliahan sehingga perkuliahan menjadi tidak efektif (Widiyono, 2020: 2337).

Kedua, penelitian yang ditulis oleh Cheung, L.L.W. dan Kan, A.C.N. (2002) yang mana mereka melakukan evaluasi terhadap faktor-faktor yang mempengaruhi prestasi peserta didik yang mengikuti e-learning. Adapun hasil temuannya adalah pelaksanaan program tutorial yang dilakukan secara tatap muka sebagai tambahan dari kegiatan tutorial mandiri dapat memberikan pengaruh yang positif dalam prestasi mahasiswa yang diukur dari nilai ujian akhir (Cheung \& Kan, 2002: 258), dan ketiga, penelitian yang dilakukan oleh Muhammad Kristiawan, dkk dengan judul "Optimalisasi Pembelajaran Daring Berbasis Aplikasi Online bagi Calon Guru Pendidikan Anak Usia Dini", dari hasil penelitiannya ditemukan bahwa aplikasi online ternyata bisa meningkatkan optimalisasi virtual learning di masa pandemi (Kristiawan et al., 2021: 1905).

Penelitian ini adalah penelitian deskriptif kuantitatif dengan menggunakan metode survei yang dilaksanakan secara online (Sugiyono, 2010: 50). Penelitian Deskriptif dipilih guna mendapatkan data hasil eksplorasi mengenai pandangan mahasiswa tentang pelaksanaan perkuliahan yang dilaksanakan secara daring. Adapun Responden penelitian ini terdiri dari mahasiswa FTIK IAIN Samarinda yang terbagi dalam tiga Program Studi yaitu; Program Studi Pendidikan Agama Islam (PAI), Program Studi Tadris Bahasa Inggris (TBI) dan Program Studi Manajemen Pendidikan Islam (MPI) di semester 2, semester 4 dan semester 6 dengan jumlah 11 kelas (342 mahasiswa). Adapun permalasahan yang dibahas pada penelitian ini adalah bagaimana respon atau pandangan mahasiswa FTIK IAIN Samarinda terhadap pembelajaran daring yang telah berlangsung pada semester ganjil tahun akademik 2020-2021?.

Adapun tujuan dilakukannya penelitian ini adalah untuk mengetahui bagaimana pandangan para mahasiswa terhadap perkuliahan online yang telah berlangsung berdasarkan apa yang telah dialami oleh para mahasiswa selama pandemi covid-19 ini sehingga hasilnya dapat digunakan untuk meningkatkan kualitas dan efektifitas pembelajaran daring di semester yang akan datang. Pembelajaran daring memang telah lama dikenal di Indonesia, namun mahasiswa belum akrab dengan pembelajaran daring karena jenjang sekolah sebelumnya belum pernah dan tidak menerapkan pembelajaran daring sama sekali (Maulipaksi, 2020: 1). 
Metode pengumpulan data yang dipakai adalah survei dengan cara menyebarkan angket kepada responden secara online kepada 342 mahasiswa FTIK IAIN Samarinda. Pengisian angket menggunakan Google Form dengan memastikan bahwa satu mahasiswa hanya dapat mengisi 1 kali. Kemudian data penelitian akan dianalisis menggunakan analisis kuantitatif deskriptif dengan teknik persentase.

\section{B. Pembahasan}

IAIN Samarinda menyelenggarakan perkuliahan daring secara penuh selama semester ganjil tahun ajaran 2020/2021 dan semester sebelumnya perkuliahan dilakukan secara blanded learning sehingga penelitian ini dilakukan saat mahasiswa di IAIN Samarinda telah mendapatkan pengalaman belajar baik pengalaman perkuliahan secara luring, maupun secara blanded learning dan sekaran secara full daring. Dengan demikian tujuan penelitian ini dapat menjawab pertanyaan tentang bagaimana pandangan mahasiswa dalam menghadapi perkuliahan yang diselengarakan secara online karena pandemi Covid-19 saat ini dan seperti apa harapan mahasiswa agar pelaksanaan perkuliahan ke depannya dapat teroganisir dengan baik sehingga mampu membentuk karakter lulusan yang sesuai dengan Capaian Pembelajaran Lulusan (CPL) sesuai dengan kurikulum.

Angket yang digunakan dalam penelitian ini berupa angket tertutup dan terbuka yang artinya responden diwajibkan untuk memilih jawaban dan mengemukakan alasan mengapa memilih jawaban tersebut atau memberikan dan menjelaskan secara detail tentang jawaban tersebut. Data demografi responden pada penelitian ini ialah mahasiswa IAIN Samarinda di Fakultas Tarbiyah dan Ilmu Keguruan pada Program Studi Pendidikan Agama Islam (PAI), Program Studi Tadris Bahasa Inggris (TBI) dan Program Studi Manajemen Pendidikan Islam (MPI) di semester 2, semester 4 dan semester 6 dengan jumlah rombongan belajar 11 kelas. Adapun rician data perkelasnya adalah sebagai berikut; (1) kelas PAI 2 semester 6 berjumlah 32 mahasiswa, (2) kelas PAI 10 semester 6 berjumlah 21 mahasiswa, (3) kelas PAI 5 semeter 2 berjumlah 43 mahasiswa, (4) kelas PAI 8 semester 6 berjumlah 33 mahasiswa, (5) kelas PAI 5 semester 6 berjumlah 25 mahasiswa, (6) kelas PAI 9 semester 4 berjumlah 27 mahasiswa, (7) kelas PAI 5 semster 4 berjumlah 31 mahasiswa, (8) kelas TBI 3 semester 2 berjumlah 30 mahasiswa, (9) kelas TBI 2 semester 2 berjumlah 30 mahasiswa, (10) kelas MPI 2 semster 2 berjumlah 38 mahasiswa, dan (10) kelas MPI 3 semster 2 berjumlah 32 mahasiswa. Total responden yang menjawab angket melalui google form berjumlah 342. Untuk melihat sebaran dari jumlah responden adalah sebagai berikut: 


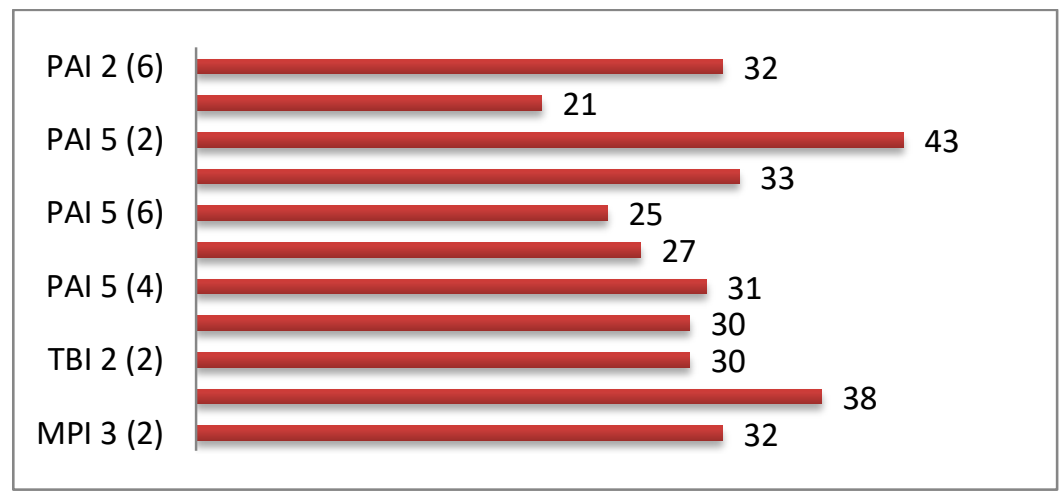

Gambar 1. Data Demografik Responden

Berdasarkan data tersebut dapat diketahui bahwa sebaran responden yang mengisi google form penelitian ini tertinggi berada di kelas PAI 5 (2) dengan jumlah 43 orang mahasiswa dan terendah di kelas PAI 10 (6) dengan jumlah 21 mahasiwa. Dari keseluruhan responden terbagi menjadi 233 orang mahasiswa berjenis kelamin perempuan dan 108 orang mahasiswa berjenis kelamin laki-laki, seperti yang tergambar dalam gambar berikut:

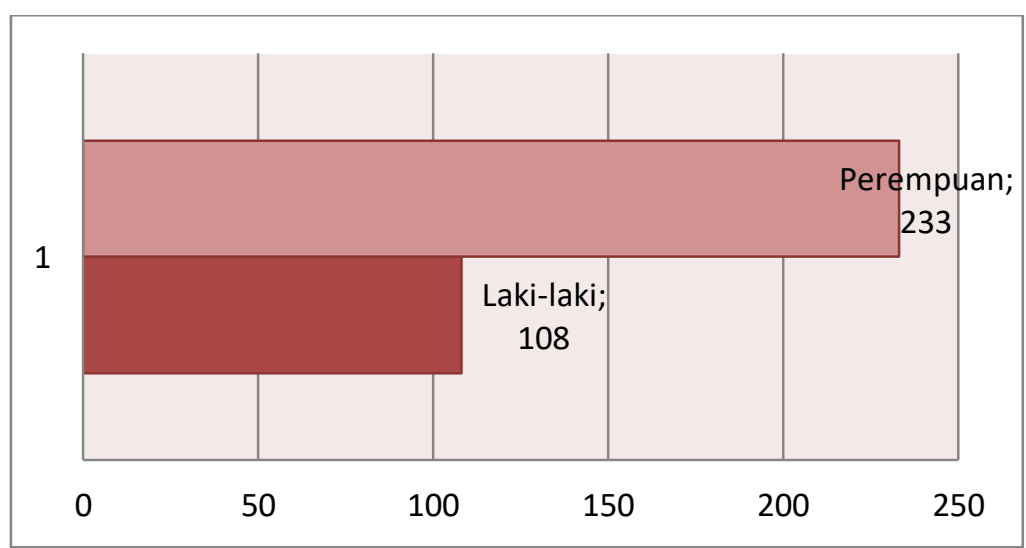

Gambar 2. Data Jenis Kelamin Responden

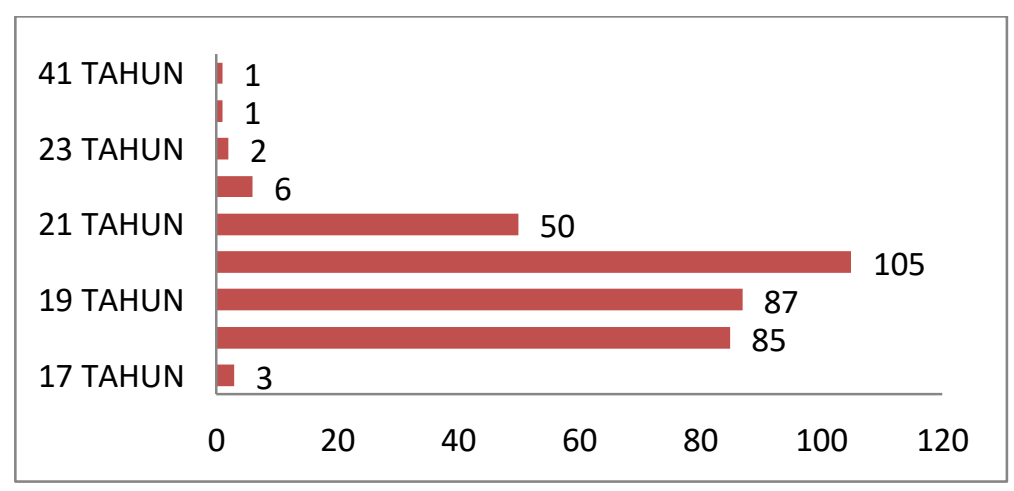

Gambar 3. Data Umur Responden 
Berdasarkan gambar 3. Dapat diketahui bahwa demografi responden berdasarkan umur telah tersebar dari umur 17 tahun hingga 41 tahun dan angka umur tertinggi responden yang mengisi survey adalah umur 21 tahun dengan jumlah 105 responden atau setara dengan 30,7\% dari keseluruhan responden.

Adapun dari hasil penelitian dapat kita ketahui bahwa aktivitas yang dilakukan oleh mahasiswa selain mengikuti perkuliahan di FTIK IAIN Saamarinda, saat pandemi ini waktu luangnya kebanyakan diisi dengan membantu kegiatan orang tua di rumah sejumlah $85 \%$ dan sebanyak $15 \%$ lainnya mengisi kegiatannya dengan berkerja atau part time seperti menjadi kurir online atau membuka usaha jualan online serta mengajar privat dan mengajar mengaji. Untuk lebih lengkapnya bisa dilihat pada persentase yang digambarkan dalam gambar berikut.

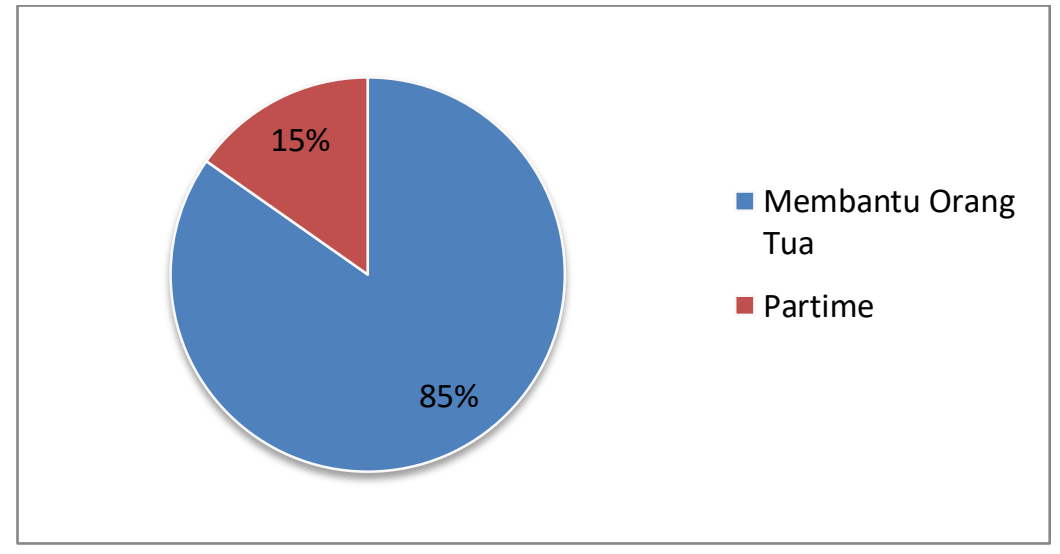

Gambar 4. Aktivitas Sehari-hari

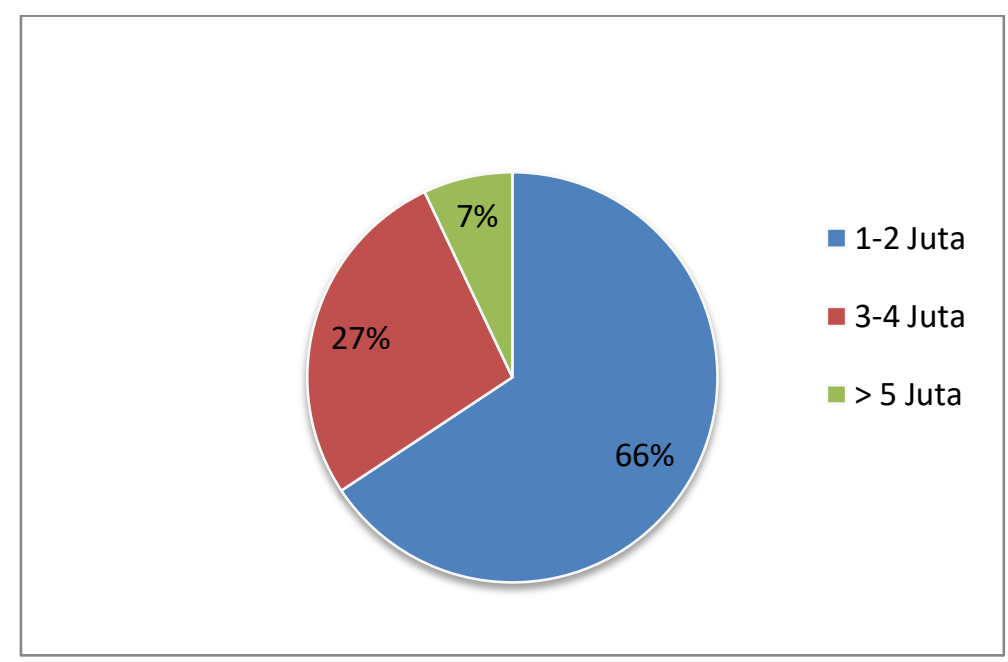

Gambar 5. Pendapatan Orang Tua 
Pada gambar tersebut dapat diketahui bahwa pendapatan orang tua responden sejumlah 66\% dengan pendapatan 1-2 juta perbulan bahkan ada beberapa responden yang mengatakan bahwa orang tuanya sudah tidak mempunyai pendapatan lagi karena di PHK dari tempat kerjanya dengan alasan pengurangan karyawan imbas dari pandemi Covid-19. Selanjutnya $27 \%$ lainnya orang tua responden memiliki pendapatan sebesar 3-4 juta perbulan dan persentase paling rendah dengan pendapatan orang tua di atas 5 juta yaitu sebanyak 7\%. Berdasarkan hasil survei ini dapat diketahui bahwa tingkat ekonomi orang tua dari responden rata-rata berada di bawah angka minimum pendapatan di Provinsi Kalimantan Timur pada 2021 yaitu Rp. 2.981.378,72 (Nadhilah, 2021: 10).

Pada awal pandemi hingga saat ini kampus IAIN Samarinda telah mengeluarkan kebijakan berupa keringanan pembayaran SPP/UKT mahasiswa namun, sebagian besar mahasiswa yang mengisi survei ini menuliskan harapannya agar UKT dapat diberi keringanan karena pendapat orang tua setiap bulannya terus mengalami penurunan yang signifikan. Hal ini menunjukan bahwa perlu kebijakan khusus yang disusun bagi masyarakat atau mahasiswa-mahasiswa yang terdampak terutama dalam hal ekonomi untuk dapat terus melanjutkan kuliah tanpa terbebani dengan beratnya membayar SPP/UKT setiap semester.

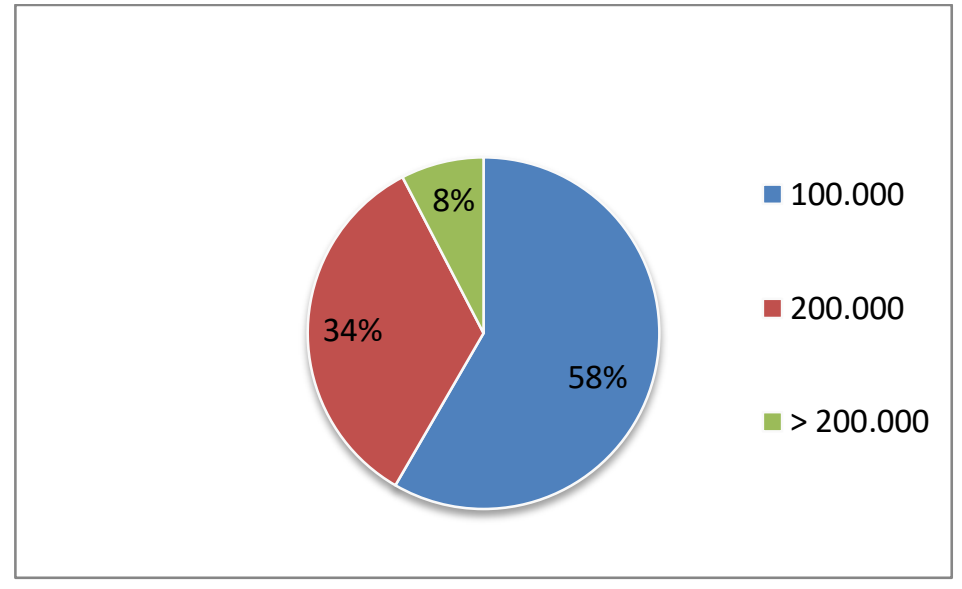

Gambar 6. Pemakaian Kuota Perbulan

Pada gambar tersebut dapat kita ketahui bahwa minimal responden menghabiskan biaya sebesar Rp. 100.000,- perbulan untuk pembelian kuota internet terutama saat kuliah daring berlangsung sebanyak 58\%, responden yang mengeluarkan biaya untuk membeli kuota perbulan sejumlah Rp. 200.000,- sebanyak 34\% responden dan sebanyak $8 \%$ responden yang mengeluarkan biaya perbulannya lebih dari Rp. 200.000,- untuk membeli kuota internet. Berdasarkan beberapa alasan yang dikeluarkan oleh mahasiswa adalah semenjak perkuliahan dilaksanakan secara daring, pengeluaran 
untuk pembelian kuota lebih besar 4 kali lipat dari biasanya, namun untuk mengatasi permasalahan tersebut agar mahasiswa bisa menghemat kuota (saat keterbatasan biaya) biasanya mahasiswa mengatasinya dengan mengurangi penggunaan kuota untuk media sosial atau main game. Jadi, kuota internet di saat pandemi covid-19 ini lebih fokus digunakan untuk mengikuti perkuliahan daring dan mengerjakan tugas-tugas kuliah saja.

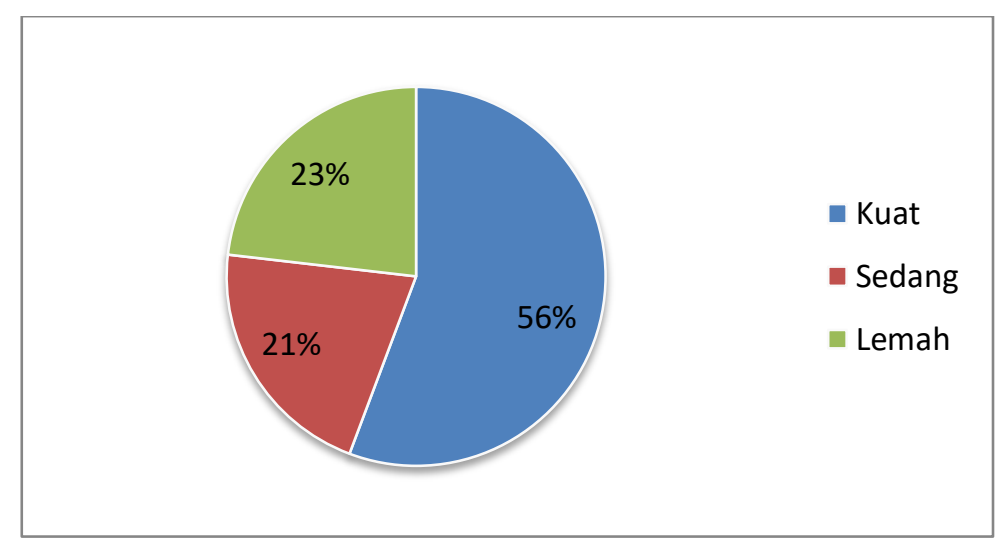

Gambar 7. Kondisi Sinyal Internet

Dari gambar di atas diketahui bahwa kondisi sinyal internet di lokasi responden saat kuliah daring memiliki kategori sinyal kuat sejumlah 56\%, kategori sinyal cukup sejumlah $21 \%$, dan kategotegori sinyal lemah sejumlah 23\%. Dengan keadaan seperti ini, bisa kita peroleh kesimpulan bahwa jaringan internet ketika perkulihan daring berlangsung cukup efektif karena rata-rata responden memiliki sinyal yang kuat sehingga tetap bisa mengikuti perkuliahan meski masing-masing responden berada di tempat yang berbeda-beda.

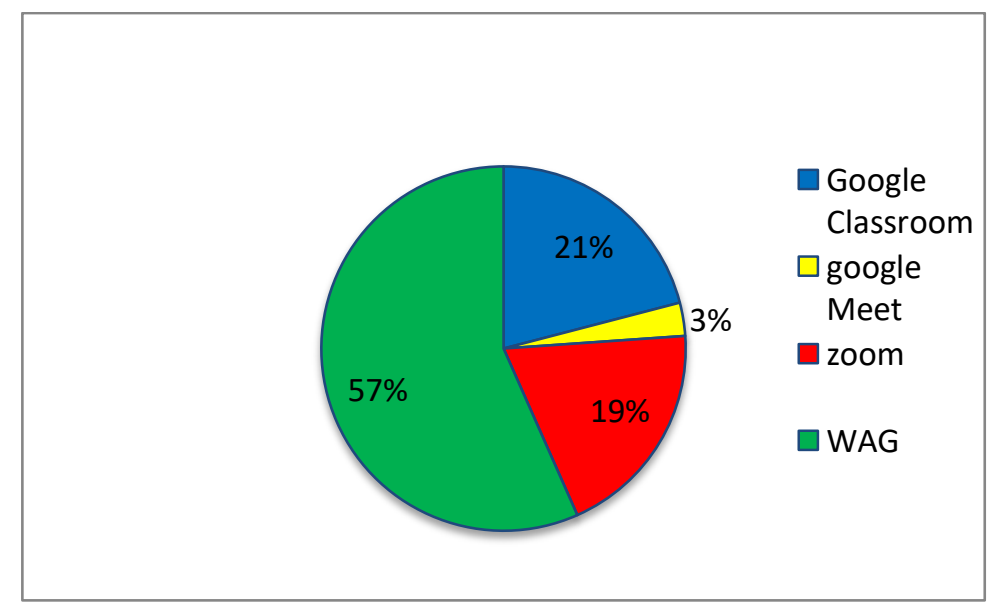

Gambar 8. Media yang disukai untuk Kuliah Daring 
Sistem perkuliahan daring di IAIN Samarinda pada tahun akademik 2020/2021 dilaksanakan dengan memanfaatkan beberapa media yang tidak asing lagi di kehidupan kita seperti google classroom, zoom, google meet, dan whatsapp grup. Berdasarkan hasil survei di atas diketahui bahwa aplikasi atau media yang disukai responden untuk kuliah daring diketahui bahwa 57\% responden lebih memiliki melaksanakan kuliah menggunakan media pembelajaran whatsaapp group, urutan kedua yang disukai responden adalah media pembelajaran google classroom yaitu sejumlah $21 \%$, selanjutnya urutan ketiga yang disukai mahasiswa adalah media pembelajaran zoom dengan jumlah $19 \%$ dan diurutan terakhir dengan persentase terendah yaitu 3\% untuk aplikasi google meet.

Adapun alasan yang dikemukakan oleh mahasiswa kenapa lebih menyukai whatsaapp group adalah lebih murah, tidak menguras kuota terlalu banyak sehingga lebih hemat kuota yang dikeluarkan, mudah diakses karena sehari-hari mahasiswa sudah menggunakan aplikasi whatsapp group untuk berkomunikasi sehingga tidak perlu belajar dan beradaptasi lagi dalam menggunakannya untuk mengikuti perkuliahan, dapat terhubung kapanpun dan dimanapun, dapat mereview kembali materi perkuliahan melalui handphone/laptop secara mudah, serta aplikasi ini mampu bertukar materi dalam bentuk dokumen, foto maupun video serta voice note dengan mudah.

Ada kelebihan tentu ada kelemahan. Kelemahan dari whatsaapp group adalah 1) karena berbasis pesan terkadang ketika perkuliahan berlangsung mahasiswa terganggu dengan pesan dari grup atau orang lain karena tidak bisa disembunyikan atau diabaikan selama perkuliahan berlangsung. 2) untuk melakukan komunikasi hanya bisa dilakukan dengan chat saja, karena kapasitas pengguna sangat terbatas apabila ingin melakukan perkuliahan menggunakan video call via whatsapp group. 3) Banyaknya pesan yang masuk mengakibatkan HP menjadi lambat. 4) tidak meratanya jaringan internet dapat menghambat mahasiswa untuk mengikuti perkuliahan yang dilakanakan secara daring sehingga apabila jaringannya lemah dapat menyulitkan mahasiswa dalam mengunduh mtaeri yang dikirim melalui whatsapp group. Bahkan untuk mahasiswa yang sudah tidak mempunyai masalah jaringan internet pun ada yang mempermasalahkan tentang biaya yang dikeluarkan guna membeli paket internet (Owusu-Fordjour et al., 2020: 93; Sadikin \& Hamidah, 2020: 111; UNESCO, 2020c). 


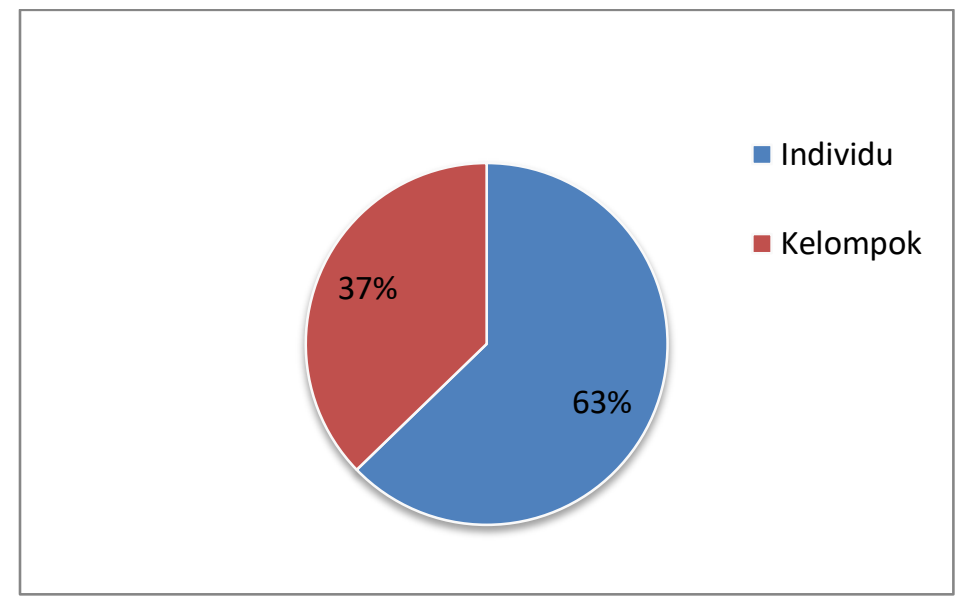

Gambar 9. Tugas yang disukai Selama Kuliah Daring

Berdasarkan gambar tersebut dapat diketahui bahwa responden lebih menyukai tugas yang diberikan oleh dosen dilaksanakan secara individu dengan jumlah responden $63 \%$ dengan alasan bahwa saat pandemi rata-rata mahasiswa pulang ke kampung halaman atau rumah masing-masing dan sulit untuk melakukan koordinasi dalam mengerjakan tugas sehingga tidak ada lagi kasus hanya beberapa mahasiswa saja yang mengerjakannya di dalam kelompok tersebut dan beberapa mahasiswa lainnya hanya menumpang nama. Untuk tugas yang dikerjakan secara kelompok dipilih mahasiswa dengan jumlah $37 \%$ dan responden mengemukakan alasan bahwa tugas kelompok lebih meringankan karena dikerjakan secara bersama-sama.

Mayoritas mahasiswa sangat berharap bahwa apapun tugas yang diberikan sebisa mungkin jangan terlalu memberatkan mahasiswa dan memungkinkan untuk dapat dikerjakan dengan mudah dalam waktu yang sesuai untuk tugas tersebut serta dosen dapat mempertimbangkan bahwa mahasiswa mengambil banyak mata kuliah dengan berbagai tugas yang berbeda-beda. Ini sama dengan hasil penelitian yang diperoleh oleh Aan Widiyono mengenai persepsi mahasiswa tentang banyaknya tugas yang diberikan dosen saat kuliah daring (Widiyono, 2020: 175). 


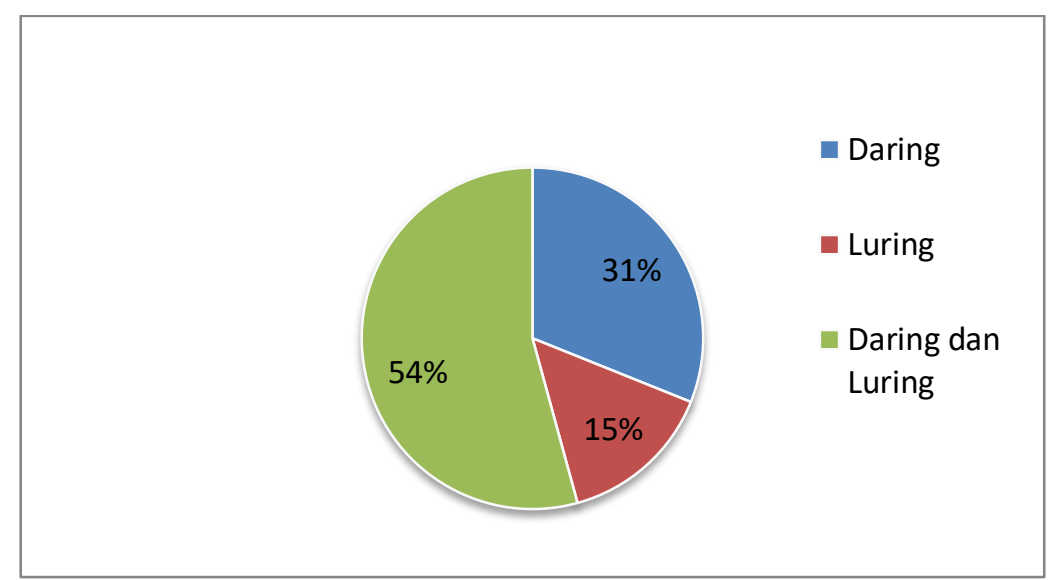

Gambar 10. Sistem Perkuliahan yang disukai

Setelah mengalami semua proses perkuliahan secara daring, luring maupun blanded learning selanjutnya mahasiswa diminta untuk mengemukakan pendapat jika pandemi covid-19 ini telah berakhir, sistem perkuliahan seperti apa yang mahasiswa inginkan. Pada gambar tersebut dapat diketahui bahwa mahasiswa yang menyukai perkuliahan dengan sistem daring dan luring atau yang dikenal dengan istilah blanded learning sejumlah 54\%, dan 34\% mahasiswa yang menyukai perkuliahan dengan sistem daring, selanjutnya $15 \%$ sisanya lebih menyukai perkuliahan dengan sistem luring.

Berdasarkan data di atas dapat diketahui bahwa perkuliahan yang dilakukan secara luring mendapatkan urutan terrendah, sehingga dapat kita simpulkan bahwa perkuliahan daring yang dilakukan sejak awal virus covid-19 masuk Indonesia secara tidak langsung telah merubah pola pikir para mahasiswa tentang sistem perkuliahan yang diinginkan untuk menyesuaikan dengan teknologi yang berkembang saat ini, namun tetap tidak meninggalkan luring untuk pematangan materi atau melakukan praktek lapangan (Cook \& Grant-Davis, 2020).

Adapun model pembelajaran yang menggabungkan metode pembelajaran tradisional/luring dan metode pembelajaran daring menjadi hybrid-learning (Affriyenni et al., 2020; Agrawal, 2020: 47; Ambarita, 2020: 68). Berdasarkan keseluruhan hasil survei diketahui bahwa rata-rata persentase hasil survei yaitu $62,7 \%$ yang termasuk dalam kategori baik. Dari sini dapat ditarik kesimpulan bahwa perkuliahan daring yang telah diterima oleh mahasiswa Fakultas Tarbiyah dan Ilmu Keguruan (FTIK) IAIN Samarinda mendapat respon positif serta bersedia dilanjutkan meskipun pandemi Covid-19 telah berakhir.

Perubahan pandangan yang dialami oleh mahasiswa IAIN Samarinda tentang sistem perkuliahan ini dikuatkan oleh penelitian La Ode Anhusadar tentang "Persepsi Mahasiswa PIAUD terhadap Kuliah Online di Masa Pandemi Covid 19" yang 
dipublikasi saat awal pandemi bulan April 2020. Hasil temuan dari penelitian yang sudah dilakukannya adalah tingkat mahasiswa dalam memahami materi yang diajarkan oleh Dosen saat perkulihan daring adalah sebanyak 40\% dan 60\% lainnya masih merasa kurang memahami materi ajar serta mahasiswa secara tidak langsung semuanya atau $100 \%$ memilih untuk melaksanakan kuliah secara tatap muka dibandingkan dengan kuliah yang dilakukan secara daring (Anhusadar, 2020: 2621). Seperti penelitian lainnya yang membahas tentang persepsi siswa terhadap pembelajaran yang dilaksanakan secara luring dan daring yang mana hasil penelitiannya dapat diketahui bahwa siswa lebih menyukai pembelajaran yang dilaksanakan secara luring daripada secara daring (Mulyono, 2020: 25).

Hal ini menunjukan bahwa saat awal perkuliahan daring berlangsung mahasiswa belum sepenuhnya siap untuk mengikuti perkuliahan daring karena belum pernah dipersiapkan sebelumnya. Namun, setelah berjalan dua semester mahasiswa mulai terbiasa dan menyukai perkulahan daring yang dibuktikan dengan peningkatan hasil survei terkait tingkat kepuasan pembelajaran daring yang terus meningkat disetiap semesternya. Adapun peningkatan hasil tersebut dipengaruh faktor mahasiswa telah mulai terbiasa dengan pembelajaran daring atau new normal pendidikan dunia termasuk di Indonesia dan dosen juga sudah mulai terbiasa serta meningkatkan kemampuan mengajar online dengan mengikuti berbagai seminar online seperti fenomena awal pandemi kita lihat bersama banyak seminar online yang dapat diikuti siapapun, dimanapun dam gratis. Hal ini mengindikasikan bahwa bukan tidak mungkin pembelajaran daring akan menjadi model pembelajaran yang paling diminati masyarakat menggantikan pembelajaran luring. Untuk itu penting menjadi perhatian kita bersama bagaimana meningkatkan efisiensi pembelajaran daring sehingga tujuan pendidikan dalam membentuk karakter lulusan dapat tercapai.

\section{Simpulan}

Perkuliahan daring yang dilakukan untuk mengatasi pandemi Covid-19 sesuai dengan ketetapan pemerintah telah dipraktikkan oleh semua Perguruan Tinggi yang berada di Indonesia termasuk di Institut Agama Islam Negeri (IAIN) Samarinda. Adapun aktivitas pembelajaran daring yang dilihat dalam penelitian ini terbagi dalam 7 aspek yaitu; (1) aktivitas sehari-hari yang dilakukan mahasiswa selain kuliah terbagi dalam dua kegiatan yaitu membantu kegiatan orang tua di rumah sejumlah $85 \%$ dan $15 \%$ lainnya mengisi kegiatannya dengan berkerja atau part time, (2) pendapatan orang tua responden yang terbesar sejumlah $66 \%$ dengan pendapatan 1-2 juta perbulan, dan tidak dipungkiri dengan adanya pandemi covid-19 juga mempengaruhi ekonomi dari orang tua responden (3) pengeluaran kuota lebih besar 4 kali lipat daripada biasanya. 
Sehingga dalam pemakaian kuota internet perbulan responden minimal menghabiskan Rp. 100.000,- perbulan terutama saat perkuliahan daring berlangsung sebanyak 58\%, (4) sinyal internet responden saat kuliah daring memiliki kategori sinyal kuat sejumlah $56 \%$, sehingga responden tetap bisa mengikuti perkuliahan meskipun dari rumah masing-masing (5) untuk media pembelajaran yang digunakan sebanyak 57\% responden lebih memilih melaksanakan perkuliahan menggunakan bantuan media pembelajaran whatsapp group dibanding media pembelajaran lainnya dikarenakan lebih mudah dan lebih murah dan tidak perlu beradaptasi lagi dalam penggunaannya, (6) responden lebih menyukai tugas dikerjakan secara individu dengan jumlah 63\%, dan (7) sistem perkuliahan yang lebih disukai responden adalah sistem daring dan luring atau blanded learning sejumlah $54 \%$.

Berdasarkan ketujuh aspek tersebut dapat diketahui bahwa mahasiswa pada Fakultas Tarbiyah dan Ilmu Keguruan (FTIK) IAIN Samarinda memberikan nilai positif pada pelaksanaan pembelajaran daring dengan nilai rata-rata persentase hasil survei yaitu $62,7 \%$ yang termasuk ke dalam kategori yang baik. Sehingga kita dapat menginterpretasikan bahwa perkuliahan daring yang telah diterima oleh mahasiswa Fakultas Tarbiyah dan Ilmu Keguruan (FTIK) IAIN Samarinda mendapat respon positif serta bersedia dilanjutkan meskipun pandemi Covid-19 telah berakhir.

\section{DAFTAR PUSTAKA}

Affriyenni, Y., \& Susanti, N., (2020). The effect of hybrid-learning on students' conceptual understanding of electricity in short-term fundamental physics course. AIP Conference Proceedings, Vol. 2215, Issue. 1.

Agrawal, A. (2020). Consultant's Report: Hybrid Systems for Delivery of Online Learning Services: An Architectural Perspective.

Ambarita, A. (2019). Pembentukan Kompetensi Pedagogik dan Profesional Guru SD melalui Hybrid Learning pada Pendidikan Profesi Guru Dalam Jabatan. Jurnal Inovasi Pendidikan dan Pembelajaran Sekolah Dasar, Vol. 3, No. 2.

Anhusadar, L. (2020). Persepsi mahasiswa PIAUD terhadap kuliah online di masa pandemi. Kindergarten: Journal of Islamic Early Childhood Education, 3 (1), 4458 . 
Cheung, L., \& Kan, A. (2002). Evaluation of factors related to student performance in a distance-learning business communication course. Journal of Education for Business.

Cook, K., \& Grant-Davis, K. (2020). Online education: Global questions, local answers.

Direktorat Pendidikan Tinggi Kemendikbut RI. Buku Panduan Penyelengaraan Semester Gasal 2020-2021 di Perguruan Tinggi, Jakarta, 2020.

Hermawan, Y. (2020). Dampak Pandemi Covid-19 terhadap Eksistensi Pendidik di Era Digital. QUALITY, Vol. 8, No. 2: 187-206.

Kristiawan, M., Aminudin, N., \& Rizki, F. (2021). Optimalisasi Pembelajaran Daring Berbasis Aplikasi Online bagi Calon Guru Pendidikan Anak Usia Dini. Jurnal Obsesi: Jurnal Pendidikan Anak Usia Dini, Vol. 5, Issue. 2: 1905-1914.

Maulipaksi, D,. Pembelajaran di Rumah Jangan Hanya Fokus pada Akademik, Ajarkan Anak Tematik tentang Covid-19, diakses 19 Juni 2020. https://www.kemdikbud.go.id/main/blog/2020/03/pembelajaran-di-rumah-janganhanya-fokus-pada-akademik-ajarkan-anak-tematik-tentang-covid19

Mulyono, W. (2020). Respon Mahasiswa Terhadap Pembelajaran Daring Pada Masa Pandemi Covid-19. Journal of Science, Technology, Education And Mechanical Engineering, Vol. 2, No. 1: 23-30.

Muthuchamy, I., \& Thiyagu, K. (2011). Blended learning-An innovative zeal in Eresources.

Nadhilah, N. (2021). Implementasi Upah Minimum Provinsi Kalimantan Timur Terhadap Usaha Kecil di Kota Samarinda. Journal of Law (Jurnal Ilmu Hukum), Vol. 4, No. 2: 1-15.

Owusu-Fordjour, C., Koomson, C., \& ... (2020). The impact of Covid-19 on learningthe perspective of the Ghanaian student. European Journal of Education Studies, Vol. 7, Issue. 3: 88-101.

Putra, I. P., Ternyata, Belajar Daring Sudah ada Sejak 1980 di Indonesia. Pendidikan Daring, diakses tanggal 19 April 2020. https://www.medcom.id/pendidikan/newspendidikan/8N00jB7N-ternyata-belajar-daring-sudah-ada-sejak-1980-di-indonesia

Rosenberg, M., \& Foshay, R. (2002). E-learning: Strategies for delivering knowledge in the digital age. Wiley Online Library. 
Sadikin, A., \& Hamidah, A. (2020). Pembelajaran Daring di Tengah Wabah Covid-19. Biodik, Vol. 6. No. 2: 109-119.

Sahroni, O., \& Nuryuniarti, R. (2020). Respon Mahasiswa Selama Pembelajaran Daring pada Mata Kuliah Pancasila. Jurnal Education and Development, vol. 8, no. 3: 37 41.

Setiawan, D., Irawati, M., Indriwati, S., Saptasari1, M, Rachmannisal, R, \& Mardiyanti, L. (2020). Pengaruh Model Pembelajaran Berbasis Masalah Dengan Metode Hybrid Learning Terhadap Keterampilan Komunikasi Mahasiswa pada Mata Kuliah Pengembangan Profesi Guru, Jurnal Pendidikan Pendidikan Biologi, Vol. 11, No. 2: 77-82.

Setyowati, L., Sukmawan, S., El-Sulukiyyah, A., Putri Ayu Lestari, \& Barotun Mabaroh. (2020). Solving The Students'errors During Their Learning Of Essay Writing In A Hybrid Setting. The International English Language Teachers and Lectures (INELTAL) Conference: 60-70.

Sugiyono, S. (2010). Educational Research Methods: Quantitative, Qualitative, and R \& D Approaches. Bandung: CV. Alfabeta.

UNESCO. (2020c). UNESCO survey highlights measures taken by countries to limit impact of COVID-19 school closures. Retrieved July 14, 2020, from https://en.unesco.org/news/unesco-surveyhighlights-measures-taken-countrieslimitimpact-covid-19-school-closures

Widiyono, A. (2020). Efektifitas perkuliahan daring (online) pada mahasiswa pgsd di saat pandemi covid 19. Jurnal Pendidikan.: 169-177.

Yuniarti, R. (2010). Potensi E-Learning Melalui Sistem Kuliah On-Line Dalam Meningkatkan Kualitas Pembelajaran Di Prodi Tata Niaga Jurusan Pendidikan Ekonomi FPEB-UPI. Manajerial: Jurnal Manajemen Dan Sistem Informasi, Vol. 9, No. 1: 66-77.

Zaking, S., Pembelajaran Jarak Jauh Permanen, Sudah Dikembangkan Sejak 1984, $\begin{array}{lllll}\text { diakses } & \text { tanggal } & 9 & \text { Juli }\end{array}$ https://www.jawapos.com/nasional/pendidikan/09/07/2020/pembelajaran-jarakjauh-permanen-sudah-dikembangkan-sejak-1984/ 